\title{
Performance of Used Tire Cushion Layer under Rockfall Impact
}

\author{
Jianhu Sun, ${ }^{1,2}$ Zhaojun Chu, ${ }^{1,2}$ Yingfang Liu, ${ }^{1,2}$ Weiming Luo, ${ }^{1,2}$ and Min Wang ${ }^{1,2}$ \\ ${ }^{1}$ Department of Civil Engineering, Logistical Engineering University, Chongqing 401311, China \\ ${ }^{2}$ Chongqing Key Laboratory of Geomechanics \& Geoenvironmental Protection, Department of Civil Engineering, \\ Logistical Engineering University, Chongqing 401311, China
}

Correspondence should be addressed to Jianhu Sun; sjh315@126.com

Received 6 September 2015; Accepted 16 December 2015

Academic Editor: Radoslaw Zimroz

Copyright (C) 2016 Jianhu Sun et al. This is an open access article distributed under the Creative Commons Attribution License, which permits unrestricted use, distribution, and reproduction in any medium, provided the original work is properly cited.

Rock shed is widely used in traffic lines against rockfall. In order to cushion rockfall impact and dissipate impact energy, cushion layer is usually adopted in rock shed. Used tire cushion layer is proposed in this paper and it can cushion rockfall impact utilizing large radial deformation of tire. Reinforced concrete structure model is built with used tire cushion layer and artificial rockfall test is carried out. Twelve tests are divided into 4 sets with different rockfall mass, rockfall height, and tire filling material. Simplified calculation model with spring-damper is derived from radial repeated compression test of used tire, which improves the calculation efficiency. Test and numerical simulation show that application of used tire cushion layer in rock shed can cushion rockfall impact and effectively reduce peak acceleration and the maximum impact force. Filling sand and gravel in tire can improve tire stiffness and energy absorption capacity but will decrease cushion effect due to its large density. With the same impact energy, light rockfall is more destructive than weight rockfall for used tire cushion layer.

\section{Introduction}

In mountainous region, frequent occurrence of geological disasters poses a serious threat to buildings and public infrastructures. Roads and railways that pass through mountains or valley are usually exposed to rockfall hazards and thus people will suffer from traffic suspension, vehicle damage, and personal injury. In recent years, scholars worldwide carried out extensive studies on rockfall hazards, proposing many rockfall hazard protection measures to reduce accidents and losses caused by rockfall disasters. Rockfall protection measures can be divided into active protection measures and passive protection measures. The passive protection measures contain many structure types such as stone-blocking fences, flexible protection system, rock shed, retaining wall, and dam [1-3]. They vary in structure form and protection energy capacity and thus can be used in different engineering situation (Figure 1) [4]. Rock shed, with high protection energy capacity, can provide direct and effective protection without changing traffic routes. Thus rock shed is widely adopted in traffic engineering as rockfall protection measures [5].
In order to mitigate the rockfall impact on rock shed, energy dissipation components or cushion layer are necessary. Delhomme et al. [6] and Mommessin et al. [7] proposed setting short CFT members between pillar and cover plate in rock shed and studied the deformation and energy absorption characteristics of the supporting member through test and theoretical analysis. He and $\mathrm{Wu}[8]$ and Boukria et al. [9] carried out experimental and numerical study on structurally dissipating rock shed (SDR) structure. However, the supporting member needs to be replaced when it reaches a certain deformation, which is unfavorable in engineering applications. Cushion layer on top of cover plate is better approach; the cushion layer can disperse contact stress between rockfall and cover plate, reduce rockfall motion acceleration, and extend function time that rockfall impact on cover plate, thus reducing the peak impact force of rockfall on plate [3]. Due to economic reasons, gravel and soil are often used as cushion layer material in engineering [10]. Study on gravel as cushion layer material in rock shed is carried out extensively. Yoshida et al. [11] and Ho et al. [12] conducted test and theoretical analysis on the sand cushion layer. Schellenberg et al. [13] and Gerber et al. [14] proposed 


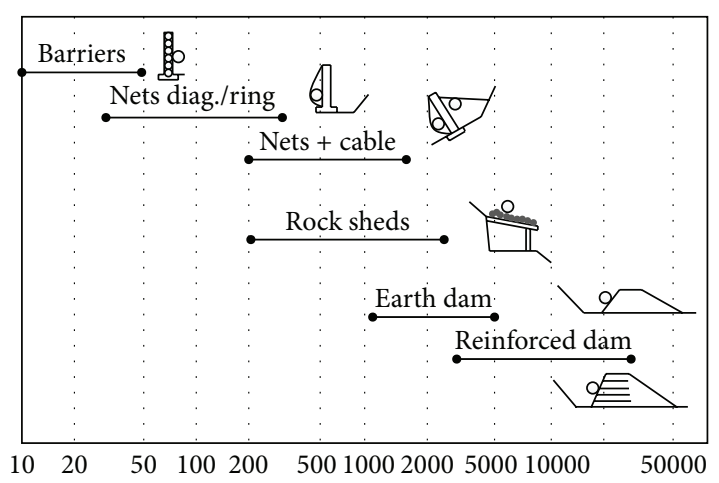

(kJ)

FIGURE 1: Energy absorption capacity of different rockfall protection structure.

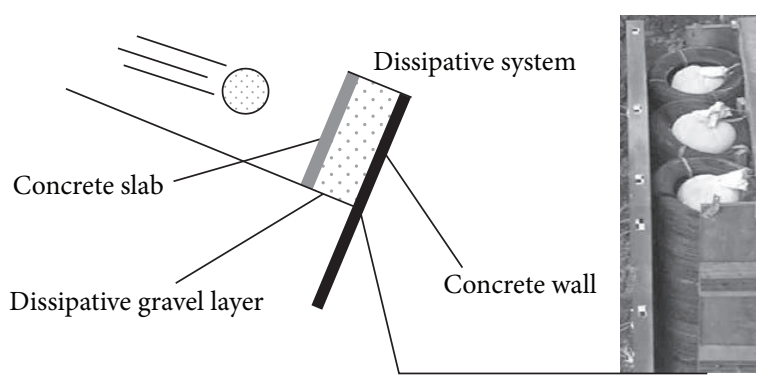

Figure 2: Sandwich cushion structure.

a new type of cushion system composed of wire mesh and foam glass and carried out large tests and theoretical analysis; results manifest cushion layer with excellent energy dissipating effect. Lorentz et al. [15] proposed a sandwich structure composed of reinforced concrete slab (Figure 2), gravel, and tires and study its performance through test. Wang et al. [5] put forward cushion layer composed of polyurethane foam and conducted experiments and numerical simulation.

A cushion layer with combination of used tires, wire, and sand bags (Figure 3 ) is proposed here and the cushion layer can be simplified as spring-damper model, with elastic deformation capacity and energy dissipation capacity. Impact test and numerical simulation study carried out on used tire demonstrate its mechanical properties with different configurations which provide a reference for optimization design and application of the new cushion layer.

\section{Rockfall Impact Test on Used Tire Cushion Layer}

2.1. Test Materials and Methods. The used tires are radial type in all tests. The thread is nearly worn flat without belt damage or any mechanical damage, cracks, or holes in the tire. As shown in Figure 4, three 195/60R15 type used tires are set up side by side in radial direction and bonded with steel wire in order to work together. Used tire cushion layer for test is positioned at center of reinforced concrete structure plate as shown in Figure 5. Two limiters are positioned to block tire rolling.

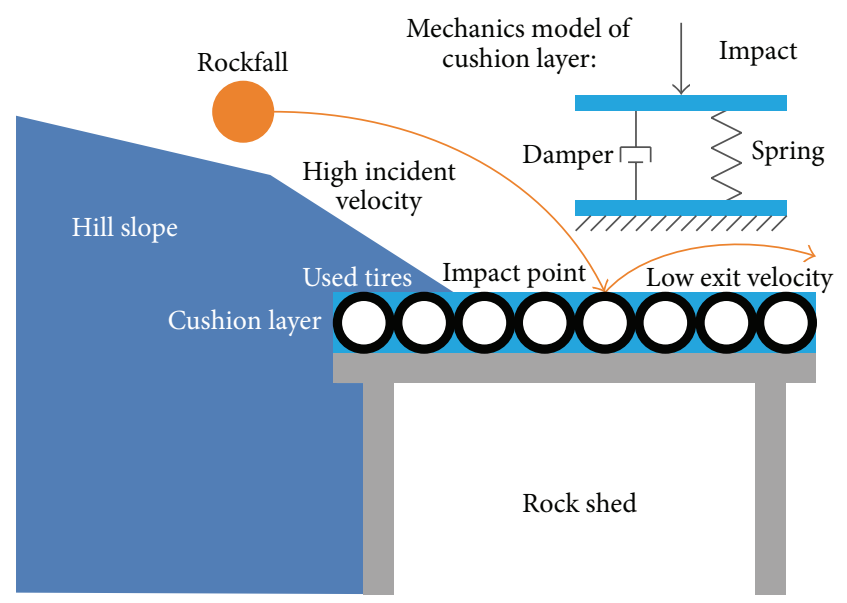

FIGURE 3: Schematic of used tire cushion layer.

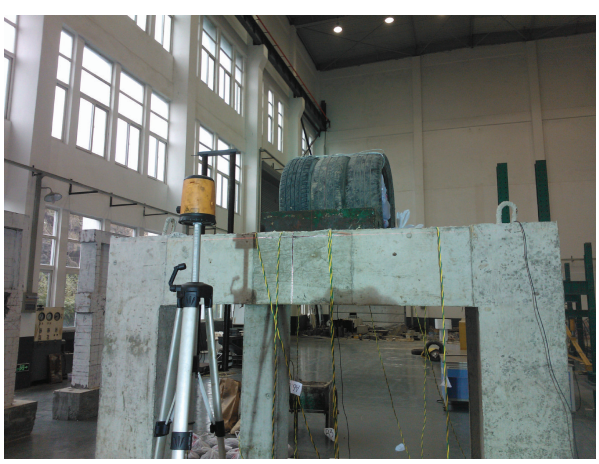

FIgURE 4: Used tire cushion layer for test.

Reinforced concrete structure shown in Figure 5 is built up by four pillars, four foundation beams, 4 upper beams, and a roof with size $2 \mathrm{~m} \times 2 \mathrm{~m} \times 2 \mathrm{~m}$. The cross-sectional dimension of pillar is $300 \mathrm{~mm} \times 300 \mathrm{~mm}$. The beam width is $200 \mathrm{~mm}$ and height is $300 \mathrm{~mm}$. The roof thickness is $100 \mathrm{~mm}$. Reinforced strength is HRB335. Concrete strength is C30. The artificial rockfall used in test is reinforced concrete structure with 14 faces as shown in Figure 5 (cube with eight corners are cut). A ring is set on top central surface of the artificial rockfall for connecting automatic decoupling devices. Under the surface of the concrete structure roof acceleration sensor with connection to Jiangsu Test ${ }^{\oplus}$ TST6200 dynamic collection instrument is set. Photron ${ }^{\otimes}$ high-speed cameras will record rockfall impact during test with frame rate $250 \mathrm{fps}$.

Rockfall tests are divided into 4 sets based on different tire filling contents and rockfall mass as shown in Table 1. There are three tests in every set for rockfall heights are different. Tires in sets 1 and 2 are filled with sand, but rockfall height is different. Tires in set 3 are filled with gravel and set 4 is empty without any filling.

Rockfall height refers to distance between lower face of rockfall and top surface of cushion layer. Rockfall impact energy is calculated with gravity $10 \mathrm{~m} / \mathrm{s}^{2}$. The calculation is based on hypothesis that potential energy is converted into kinetic energy without considering air resistance and others. 
TABLE 1: Test conditions.

\begin{tabular}{|c|c|c|c|c|c|}
\hline \multirow{2}{*}{ Set number. } & \multirow{2}{*}{ Serial number } & \multirow{2}{*}{ Filling contents } & \multicolumn{3}{|c|}{ Artificial rockfall } \\
\hline & & & $m / \mathrm{kg}$ & $h / \mathrm{m}$ & Impact energy $/ \mathrm{kJ}$ \\
\hline \multirow{3}{*}{ A } & $1 \#$ & Sand & 100 & 1 & 1 \\
\hline & $2 \#$ & Sand & 100 & 2 & 2 \\
\hline & $3 \#$ & Sand & 100 & 3 & 3 \\
\hline \multirow{3}{*}{ B } & $4 \#$ & Sand & 200 & 0.5 & 1 \\
\hline & $5 \#$ & Sand & 200 & 1 & 2 \\
\hline & $6 \#$ & Sand & 200 & 1.5 & 3 \\
\hline \multirow{3}{*}{ C } & $7 \#$ & Gravel & 100 & 1 & 1 \\
\hline & $8 \#$ & Gravel & 100 & 2 & 2 \\
\hline & 9\# & Gravel & 100 & 3 & 3 \\
\hline \multirow{3}{*}{$\mathrm{D}$} & 10\# & None & 100 & 1 & 1 \\
\hline & $11 \#$ & None & 100 & 2 & 2 \\
\hline & 12\# & None & 100 & 3 & 3 \\
\hline
\end{tabular}

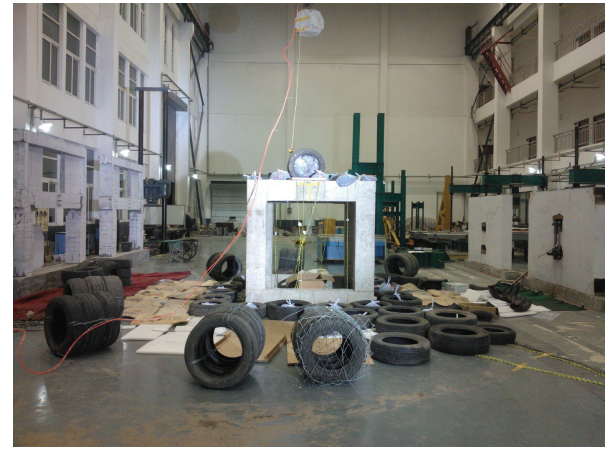

FIgURE 5: Test configuration.

The decoupling device is connected to the crane and rockfall and then crane will lift rockfall to a set height through automatic unhooking device. TST6200 and highspeed camera are turned on. Switch the decoupling device to release rockfall. TST6200 and high-speed camera will record data as configured. Tests are carried out in accordance with the order of serial number in Table 1 .

2.2. Test Results. As observed in the tests, rockfall will impact tire cushion layer or concrete structure roof once or more after first impact on and rebound from tire cushion layer (as shown in Figure 6). The subsequent impact and rebound are disregarded and only the first impact of rockfall on cushion layer is studied. Force between rockfall and cushion layer and acceleration of concrete structure roof under impact are taken into consideration.

According to Newton's third law, the average impact force of rockfall applied on tire cushion layer equals average force of tire cushion layer applied on rockfall written $f$ :

$m$ : rockfall mass,

$g=10 \mathrm{~m} / \mathrm{s}^{2}$ : gravity acceleration,

$t_{1}$ : the first time that rockfall comes in contact with tire cushion layer, $v_{1}$ : rockfall impact velocity corresponding with $t_{1}$; velocity is set positive with antigravity direction,

$t_{2}$ : the first time that rockfall rebounds apart from tire cushion layer,

$v_{2}$ : rockfall rebound velocity corresponding with $t_{2}$,

$t_{2}-t_{1}$ : time duration that rockfall comes in contact with tire cushion layer.

Take rockfall as analysis object and, according to momentum theorem, we have

$$
\begin{aligned}
(f-m g)\left(t_{2}-t_{1}\right) & =m\left(v_{2}-v_{1}\right), \\
f & =\frac{m\left(v_{2}-v_{1}\right)}{\left(t_{2}-t_{1}\right)}+m g .
\end{aligned}
$$

According to the energy conservation law, the rockfall impact velocity $v_{1}=-\sqrt{2 g h}$, while the rebound velocity $v_{2}$ and contact time $t_{2}-t_{1}$ are to be calculated by image obtained via high-speed camera.

Frame rate of high-speed camera is set to $250 \mathrm{fps}$ considering calculation requirement and light condition. Image that corresponds with $t_{1}$ is $n_{1}$ frame and image that corresponds with $t_{2}$ is $n_{2}$ frame. $n_{3}$ frame is captured while rockfall rebounds to its peak in its track after first impact. We have

$$
\begin{aligned}
t_{2}-t_{1} & =\frac{n_{2}-n_{1}}{250}, \\
t_{3}-t_{2} & =\frac{n_{3}-n_{2}}{250}, \\
v_{2} & =g\left(t_{3}-t_{2}\right)=\frac{g\left(n_{3}-n_{2}\right)}{250} .
\end{aligned}
$$

In summary, we have

$$
f=m \frac{g\left(n_{3}-n_{2}\right)+250 \sqrt{2 g h}}{n_{2}-n_{1}}+m g .
$$

Figure 6 shows the first impact of rockfall on cushion layer in test 2\#. Average force of tire cushion layer applied on rockfall 


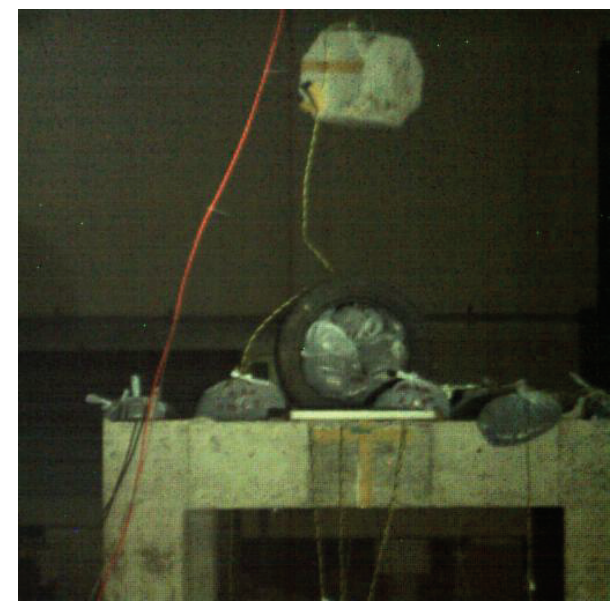

(a) Rockfall entering camera capture range (34 frames)

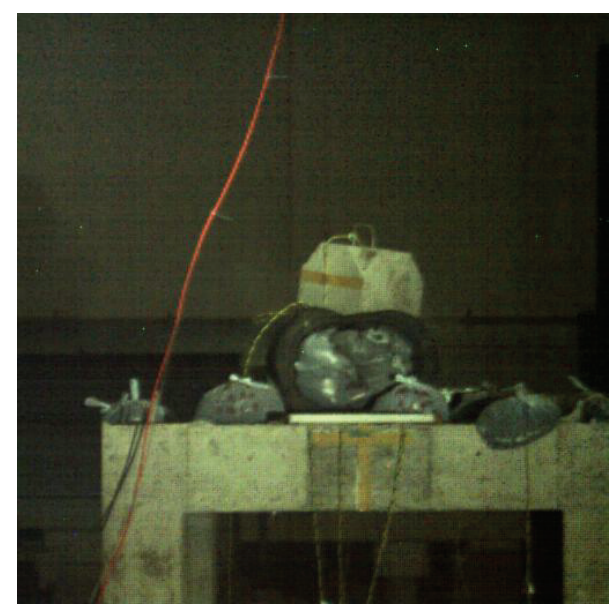

(c) Rockfall impact to its lowest point in its track (79 frames)

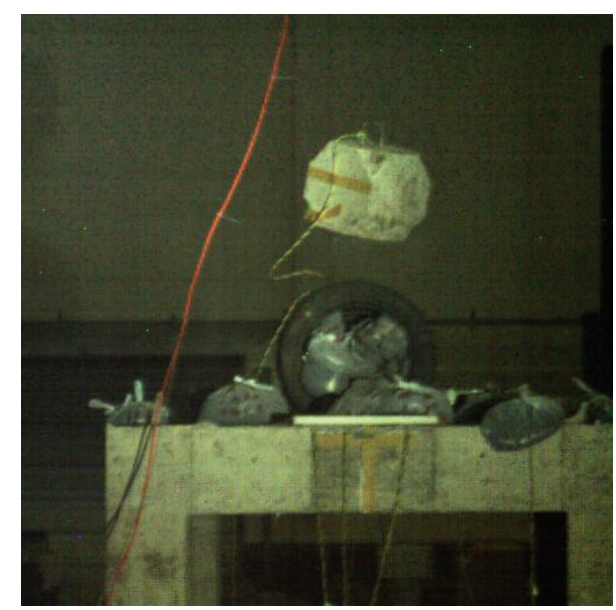

(e) Rockfall rebound to its peak in its track after first impact ( $n_{3}=163$ frames)

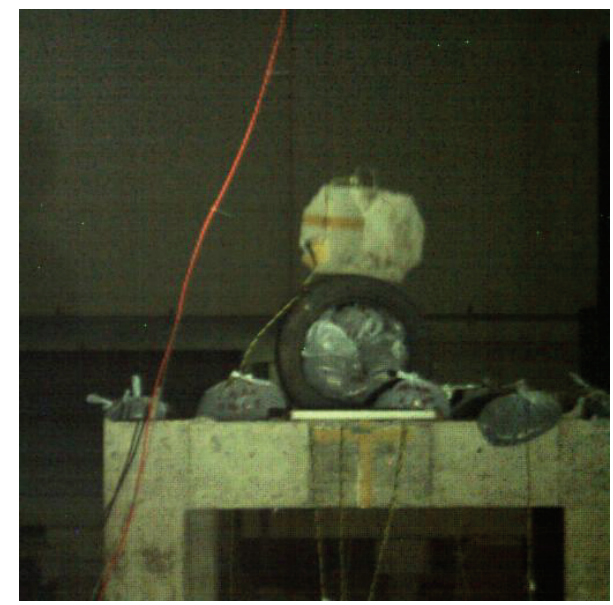

(b) The first time that rockfall comes in contact with tire cushion layer ( $n_{1}=59$ frames)

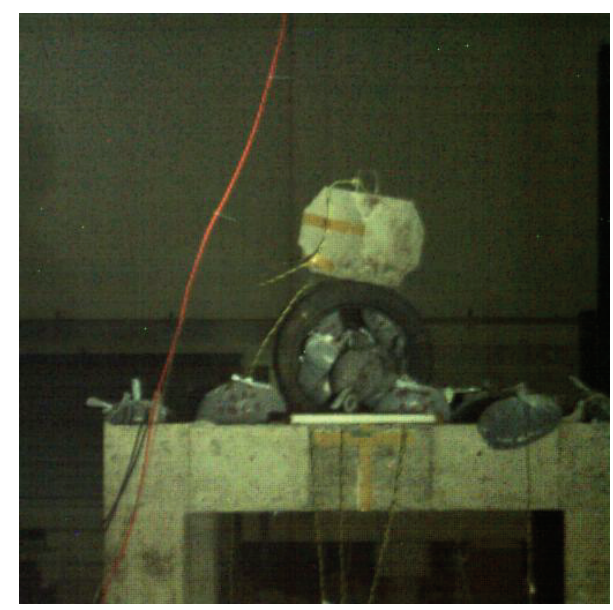

(d) The first time that rockfall rebounds apart from tire cushion layer $\left(n_{2}=110\right.$ frames)

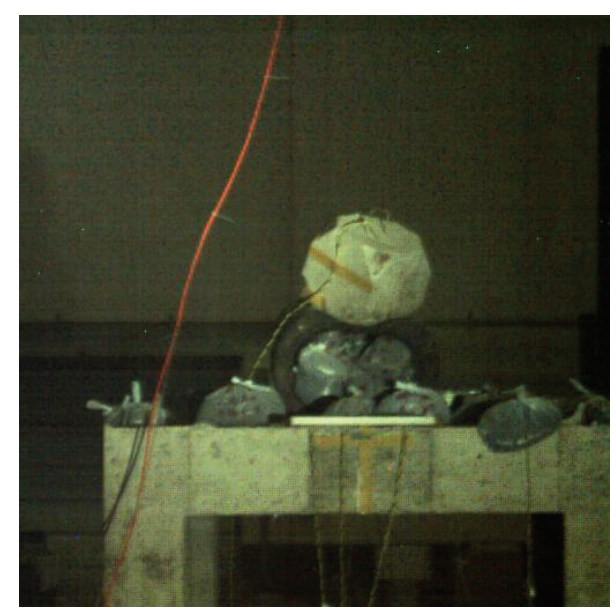

(f) Rockfall impact cushion layer for the second time (246 frames)

FIGURE 6: The rockfall impact tack captured by camera in test 2\#. 
TABLE 2: Average force $f$ and peak acceleration $a_{\max }$ in all tests.

\begin{tabular}{|c|c|c|c|c|c|c|c|c|}
\hline Set number & Serial number & $n_{1}$ & $n_{2}$ & $n_{3}$ & $v_{2} /(\mathrm{m} / \mathrm{s})$ & $t_{2}-t_{1} / \mathrm{s}$ & $f / \mathrm{kN}$ & $a_{\max } /\left(\mathrm{m} / \mathrm{s}^{2}\right)$ \\
\hline \multirow{3}{*}{ A } & $1 \#$ & 172 & 222 & 267 & 1.800 & 0.200 & 4.136 & 0.12 \\
\hline & $2 \#$ & 59 & 110 & 163 & 2.120 & 0.204 & 5.139 & 0.37 \\
\hline & $3 \#$ & 210 & 263 & 323 & 2.400 & 0.212 & 5.786 & 0.78 \\
\hline \multirow{3}{*}{ B } & $4 \#$ & 265 & 323 & 350 & 1.080 & 0.232 & 5.657 & 0.17 \\
\hline & $5 \#$ & 275 & 335 & 362 & 1.080 & 0.240 & 6.627 & 0.70 \\
\hline & $6 \#$ & 312 & 375 & 404 & 1.160 & 0.252 & 7.268 & 1.36 \\
\hline \multirow{3}{*}{ C } & 7\# & 69 & 116 & 151 & 1.400 & 0.188 & 4.123 & 0.20 \\
\hline & $8 \#$ & 195 & 244 & 284 & 1.600 & 0.196 & 5.043 & 0.51 \\
\hline & 9\# & 244 & 294 & 339 & 1.800 & 0.200 & 5.773 & 0.93 \\
\hline \multirow{3}{*}{$\mathrm{D}$} & $10 \#$ & 116 & 180 & 223 & 1.720 & 0.256 & 3.419 & 0.13 \\
\hline & $11 \#$ & 205 & 276 & 338 & 2.480 & 0.284 & 4.100 & 0.16 \\
\hline & $12 \#$ & 138 & 212 & 287 & 3.000 & 0.296 & 4.630 & 0.20 \\
\hline
\end{tabular}

can be calculated based on $n_{1}, n_{2}$, and $n_{3}$ using formula (3). Average force of tire cushion layer applied on rockfall and peak acceleration $a_{\max }$ of concrete structure slab under impact in all 4 sets of tests are given in Table 2.

2.3. Rockfall Impact Energy. Within each set of tests, time duration in which rockfall contacts tire cushion layer increases with rockfall impact energy. Contact time increase step is small while tires are filled with sand or gravel. Contact time increases 2 5\% with adjacent rockfall impact energy. Contact time increase step is large while tires are empty without any filling. Contact time increases 2 5\% with adjacent rockfall impact energy.

Within each set of tests, peak acceleration of concrete structure slab increases with rockfall impact energy. Peak acceleration increment is large while tires are filled with sand or gravel. Peak acceleration increases $82 \sim 312 \%$ with adjacent rockfall impact energy. Peak acceleration increment is small while tires are empty without any filling. Increment increases 23 25\% with adjacent rockfall impact energy.

Average force of tire cushion layer applied on rockfall and rockfall rebound velocity increase with impact energy within each set of tests.

Tires are all filled with sand in test set A and set B and rockfall mass is $100 \mathrm{~kg}$ and $200 \mathrm{~kg}$, respectively, for test set A and set $\mathrm{B}$. With the same rockfall impact energy, contact time duration, contact force, and peak acceleration of concrete slab are all bigger in set $\mathrm{A}$ than that in set $\mathrm{B}$, but rockfall rebound velocity is opposite.

In summary it is obvious that contact time and force, rockfall rebound velocity, and peak acceleration of concrete slab increase with rockfall impact energy. But with the same impact energy, rockfall with large mass is unfavorable.

2.4. Filling Content. In test sets $\mathrm{A}, \mathrm{C}$, and $\mathrm{D}$, rockfall masses are all $100 \mathrm{~kg}$. But, with the same impact energy, tire cushion layer shows different cushion capacity due to different tire filling content.

The contact time in sets A and C is basically the same and contact time in set $\mathrm{D}$ is the longest among the three sets with about $8 \%$ more than sets $\mathrm{A}$ and $\mathrm{C}$.
Average contact force in set $\mathrm{D}$ is the smallest among the test sets A, C, and D. Average contact force in sets A and C is basically the same with average $23 \%$ increase compared with set D.

Rockfall rebound velocity in set $\mathrm{C}$ is the smallest within the test sets A, C, and D which indicates that cushion layer filled with gravel shows good energy absorption property. The energy absorption capacity derives from gravel crushing and friction.

In set $\mathrm{D}$, peak acceleration of slab is the smallest within the three sets of tests. Peak acceleration of slab in sets A and C is basically the same with average $197 \%$ higher than that in set D.

All in all, within the four sets of tests, used tire cushion layer without any filling performs better in cushion rockfall impact and reduces peak acceleration of rock shed slab and is lighter in weight compared with cushion layer filled with sand or gravel which is preferable. Due to the test conditions limitation, test carried out with low rockfall impact energy and used tire deformation is small. Used tire cushion layer will be compressed and flattened. Filled with sand or gravel, tire stiffness increases and tire can also absorb some impact energy from crush and friction of sand or gravel. However, different from [15], sand and gravel with large density will make it unfavorable in rock shed for it will largely increase dead load. In actual engineering application, cushion layer can be set up with multilayer and filled with polyurethane foam, polystyrene, low-density industrial waste, or other lightweight materials with a cell structure in order to improve the rigidity and energy absorption capacity of cushion layer.

\section{Numerical Simulation}

3.1. Simplified Calculation Model. Zhang [16] and Wang and Yang [17] carried out finite element simulation of tire and simulation results are in good agreement with the experimental results. In order to improve computational efficiency, this paper simplifies the tire calculation model. 195/60R15 type used tire is radially compressed three times sequentially using universal testing machine with range of $200 \mathrm{kN}$ and loading speed of $200 \mathrm{~mm} / \mathrm{min}$; each compression terminates when 


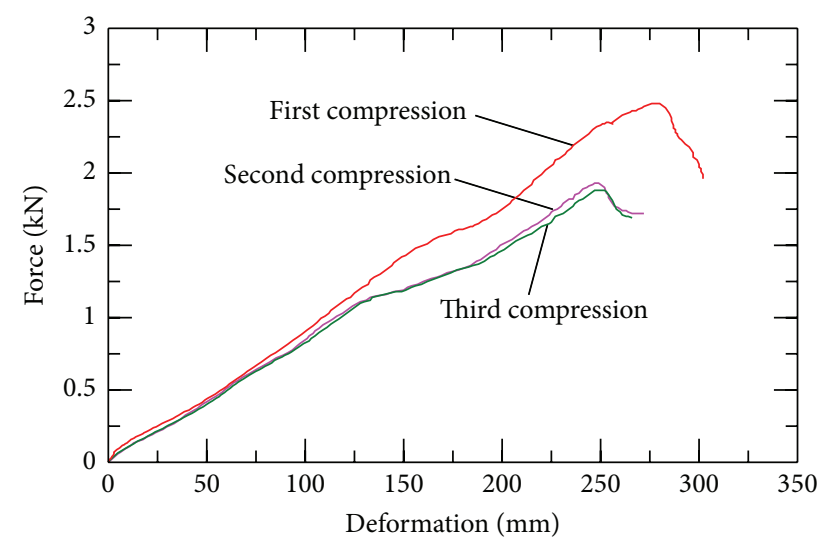

FIGURE 7: The force-deformation curve of tire under repeated radial compression.

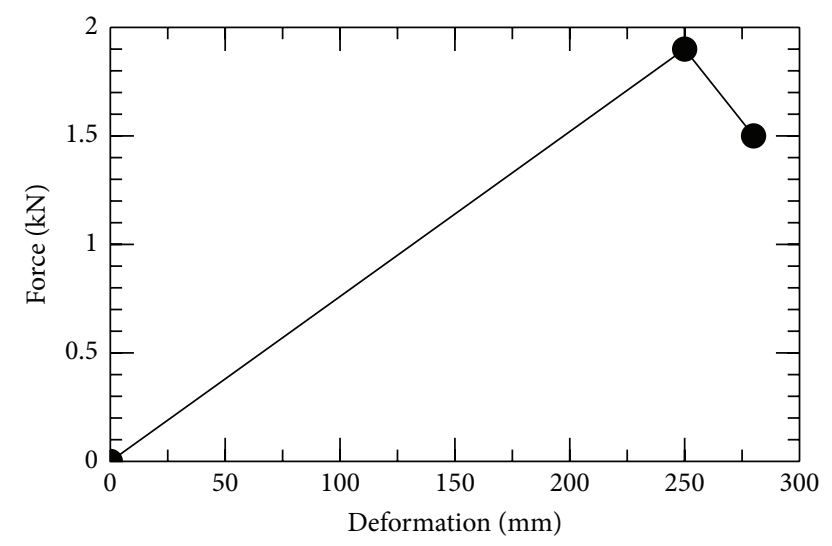

Figure 8: Simplified Force-displacement curve of used tires under radial compression.

tire gets instable. Tires basically restore to original form after unloading with little deformation.

The force-deformation curve of tire under repeated compression test is shown in Figure 7. From the forcedeformation curves of the two types of tires, the forcedeformation curves of the three times of compression coincide in value and trend under small deformation. With tire deformation increases, tire bears lager force in first compression than the second or third compression with same deformation, but the second and third compression curves are almost identical. It shows that tires after first compression perform stable mechanical property.

Tires show good elastic properties in radial compression tests that are similar to mechanical properties of spring, establishing spring-damper model using COMBI165 element (spring-damper element) to simulate used tire cushion layer under rockfall impact. Take the average of the second and third compression force-deformation curves and then simplify them to broken line shown in Figure 8.

Figure 9(a) is tire model established in accordance with the literature $[16,17]$ and Figure 9(b) is simplified calculation model using spring-damper element. In Figure 9(a), the upper blue color part is FEM model of rockfall, the red color
TABLE 3: The contrast of the average forces in the test and numerical simulation.

\begin{tabular}{lccc}
\hline Rockfall impact energy/kJ & 1 & 2 & 3 \\
\hline Test/kN & 3.42 & 4.10 & 4.63 \\
Simulation/kN & 4.28 & 5.78 & 6.90 \\
\hline
\end{tabular}

TABLE 4: The contrast of the maximal compressed length.

\begin{tabular}{lccc}
\hline Rockfall impact energy/kJ & 1 & 2 & 3 \\
\hline Test $/ \mathrm{m}$ & 0.26 & 0.32 & 0.40 \\
Simulation/m & 0.32 & 0.40 & 0.45 \\
\hline
\end{tabular}

part at the bottom is concrete slab, and the middle part is FEM model of a tire. In Figure 9(b), the meaning of upper blue color part and the red color part at the bottom the same as mentioned above in Figure 9(a). The middle part is a simplified model of tire with green upper plate and lower plate and middle yellow spring elements. Contact force between tire and slab derived separately from tire model and simplified model match well in trends, peak value, and time duration as shown in Figure 10. Calculation time needed for tire model and simplified model is about ten hours and within 20 minutes. Simplified model is better in efficiency and it is easy to obtain parameters by experiment.

Concrete structural model is established in accordance with the actual property in rockfall impact test. Simulations were carried out with rockfall $100 \mathrm{~kg}$ and falling height $1 \mathrm{~m}$, $2 \mathrm{~m}$, and $3 \mathrm{~m}$. Average impact force applied on slab and tire deformation derived from simulation with comparison with test results are listed in Tables 3 and 4 . Test results are smaller than that of simulation for bottom of artificial rockfall which cannot be adjusted parallel to top surface of tire cushion layer, so rockfall bottom surface cannot be parallel to top surface of tire cushion layer during impact and rebound. Rockfall moves with component of horizontal velocity result in low value compared with simulation.

3.2. Simulation Conditions. Performances of concrete slab with and without used tire cushion layer are both simulated in two series simulations as shown in Table 5. Simplified calculation model is used here. Rockfalls in simulation with energy $1 \mathrm{~kJ}, 2 \mathrm{~kJ}, 3 \mathrm{~kJ}, 5 \mathrm{~kJ}$, and $10 \mathrm{~kJ}$ are different in mass and falling height. In series one, rockfalls are with different falling height and with the same mass, $100 \mathrm{~kg}$. In series two, rockfalls are with different mass and with the same falling height, $2 \mathrm{~m}$.

3.3. Simulation Results and Analysis. Simplified model with advantage of high computational efficiency and easy access to parameters can be used to simulate the rockfall impact process and results can reflect used tire cushion layer performance. Results derived from simulation of rockfall with different mass and falling height impact slab without cushion layer given in Tables 6 and 7 show that maximum impact force and displacement of slab increase with rockfall energy. With same rockfall energy and increase of rockfall mass, impact force of slab decreases and peak displacement of slab increases. 


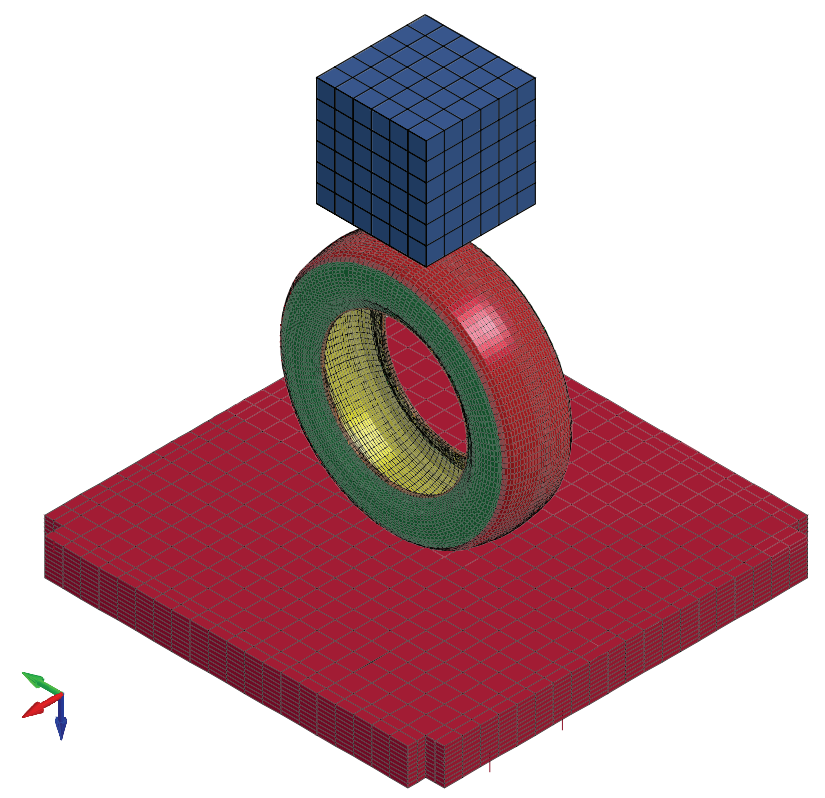

(a) Tire model

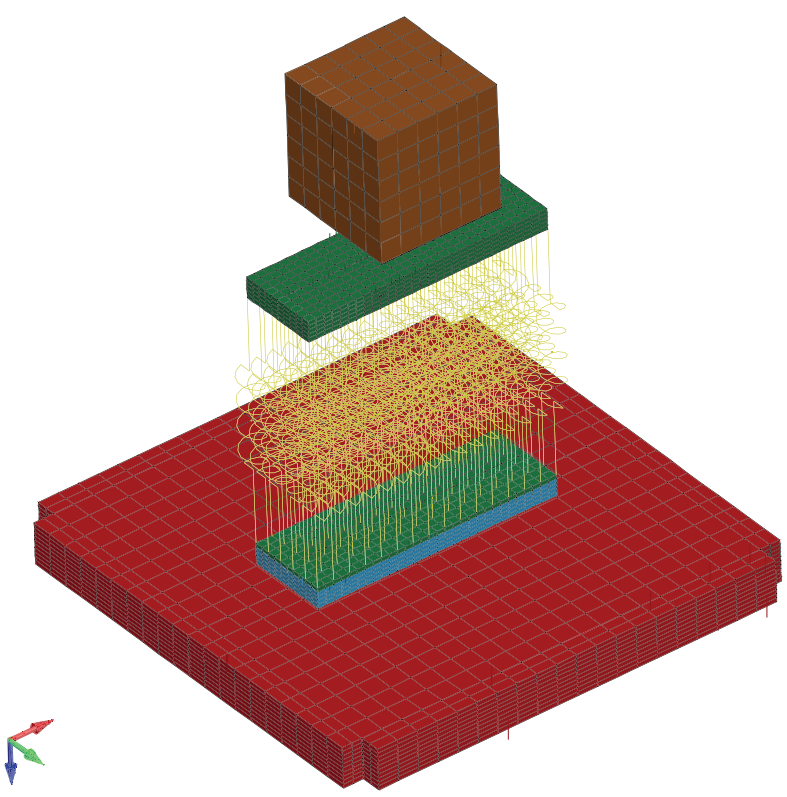

(b) Simplified calculation model

FIgURE 9: Calculation model of tire.

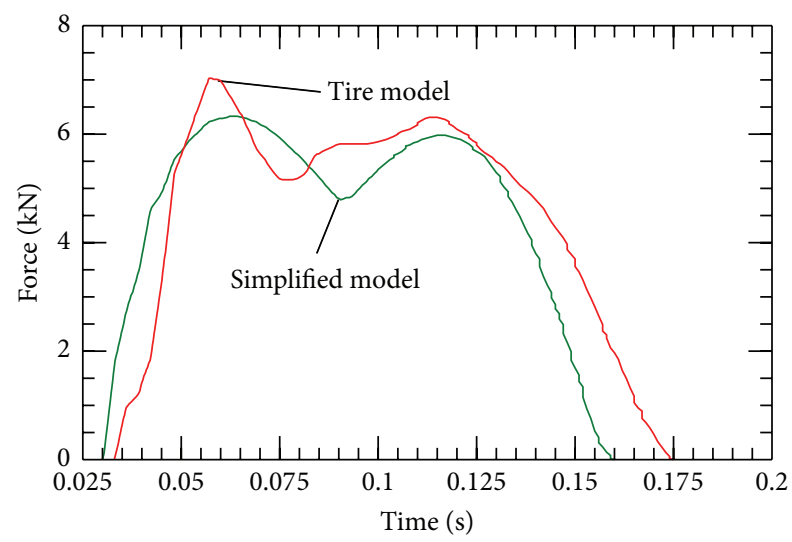

Figure 10: Contrast of force-time curves.

TABLE 5: Rockfall configuration in simulation.

\begin{tabular}{lccccc}
\hline \multirow{2}{*}{ Series } & \multicolumn{5}{c}{ Rockfall configuration $m * h /(\mathrm{kg} * \mathrm{~m})$} \\
& $1 \mathrm{~kJ}$ & $2 \mathrm{~kJ}$ & $3 \mathrm{~kJ}$ & $5 \mathrm{~kJ}$ & $10 \mathrm{~kJ}$ \\
\hline One & $100 * 1$ & \multirow{2}{*}{$100 * 2$} & $100 * 3$ & $100 * 5$ & $100 * 10$ \\
Two & $50 * 2$ & & $150 * 2$ & $250 * 2$ & $500 * 2$ \\
\hline
\end{tabular}

TABLE 6: Maximum impact force of slab without cushion layer.

\begin{tabular}{lccccc}
\hline \multirow{2}{*}{ Series } & \multicolumn{5}{c}{ Maximum impact force/kN } \\
& $1 \mathrm{~kJ}$ & $2 \mathrm{~kJ}$ & $3 \mathrm{~kJ}$ & $5 \mathrm{~kJ}$ & $10 \mathrm{~kJ}$ \\
\hline One & 2470 & \multirow{2}{*}{3369} & 4051 & 5082 & 6717 \\
Two & 2774 & & 3576 & 3817 & 4465 \\
\hline
\end{tabular}

Results derived from simulation of rockfall with different mass and falling height impact slab with cushion layer given in Figure 11 show that maximum impact force increases with
TABLE 7: Maximum displacement of slab without cushion layer.

\begin{tabular}{lccccc}
\hline \multirow{2}{*}{ Series } & \multicolumn{5}{c}{ Maximum displacement $/ \mathrm{mm}$} \\
& $1 \mathrm{~kJ}$ & $2 \mathrm{~kJ}$ & $3 \mathrm{~kJ}$ & $5 \mathrm{~kJ}$ & $10 \mathrm{~kJ}$ \\
\hline One & 2.35 & \multirow{2}{*}{3.38} & 4.21 & 5.68 & 8.65 \\
Two & 1.8 & & 4.79 & 7.32 & 12.04 \\
\hline
\end{tabular}

rockfall energy. With same rockfall energy and increase of rockfall mass, peak impact force increases.

With rockfall configurations $250 * 2,100 * 10$, and $500 * 2$, the tire was completely crushed. With the same rockfall impact energy $5 \mathrm{~kJ}$, tire cannot be completely crushed by rockfall with configuration $100 * 5$ but was completely crushed by rockfall with configuration $250 * 2$. With the same rockfall impact energy $10 \mathrm{~kJ}$, peak impact force is $1080 \mathrm{kN}$ with rockfall configuration $500 * 2$ and peak impact force is $500 \mathrm{kN}$ with rockfall configuration $100 * 10 . P=\sqrt{2 m E}$ can be derived From $E=m v^{2} / 2, P=m v$ ( $E$ is kinetic energy, $P$ is the momentum) which means that, with the same kinetic energy, rockfall momentum is relatively large with large mass. Average impact force in each impact process is listed in Table 8. It shows that, with the same rockfall impact energy, average impact force and tire deformation increase with rockfall mass.

The maximum impact force applied on slab with cushion layer is much less than that without cushion layer from comparison of Table 6 with Figure 11. Used tire cushion layer shows great cushion effect for rockfall impact.

\section{Conclusion}

Rock shed is commonly used in traffic line disaster protection. In order to improve rock shed performance, impact 


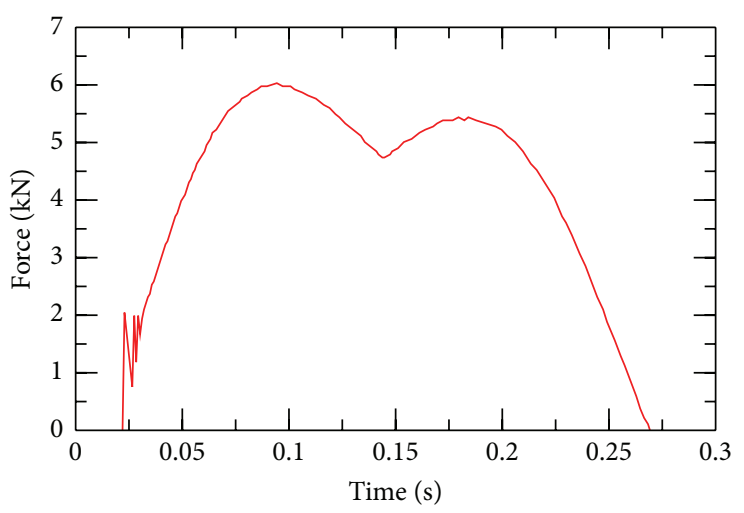

(a) $100 * 1$

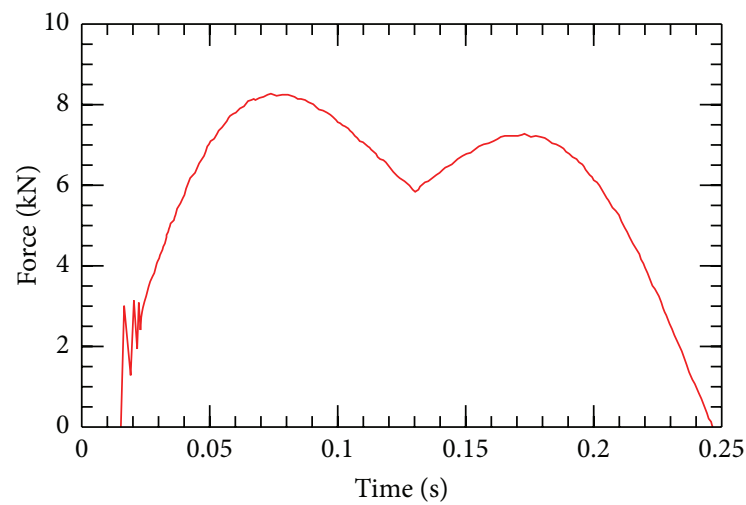

(c) $100 * 2$

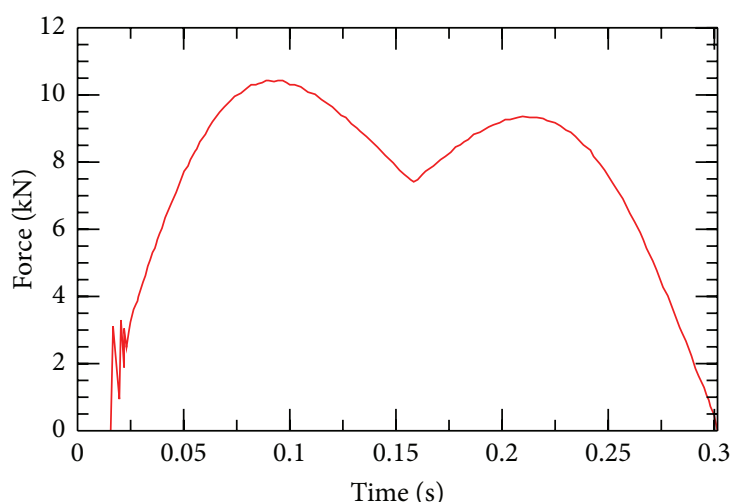

(e) $150 * 2$

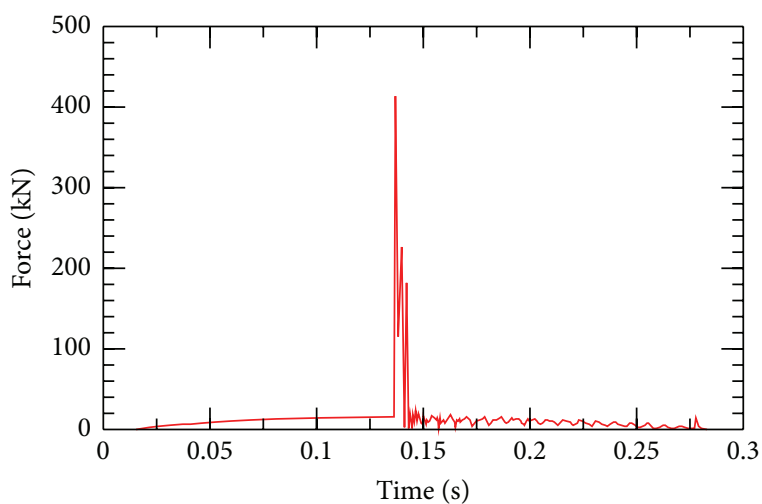

(g) $250 * 2$

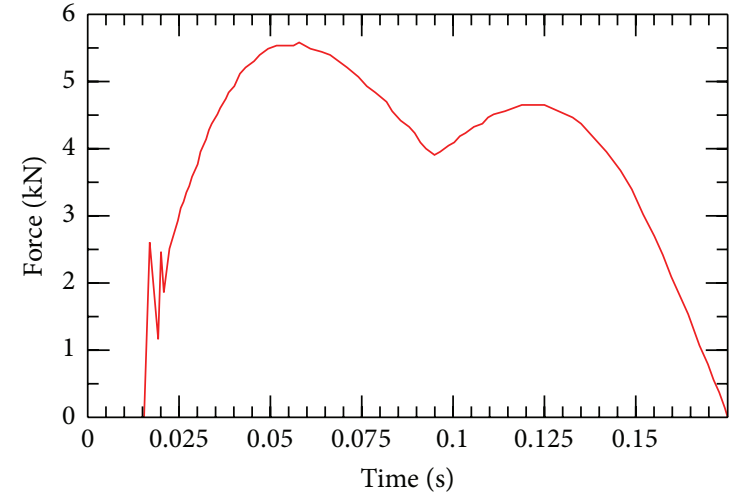

(b) $50 * 2$

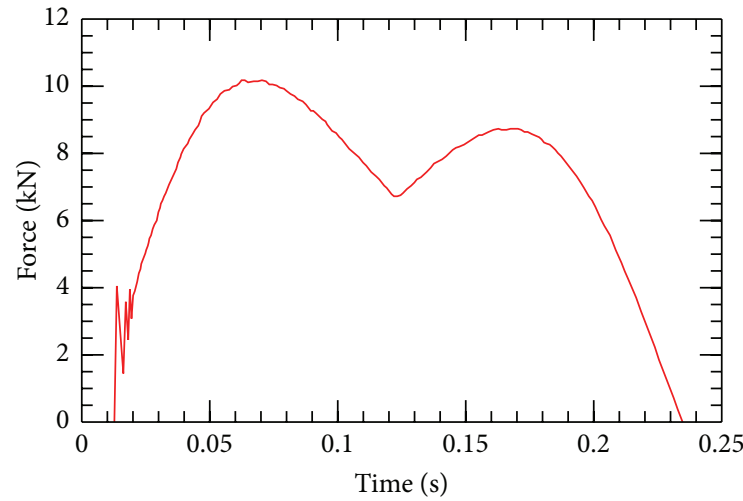

(d) $100 * 3$

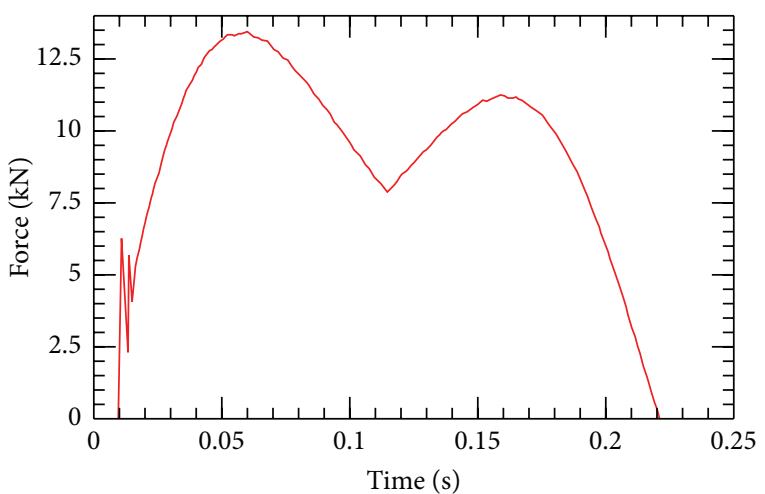

(f) $100 * 5$

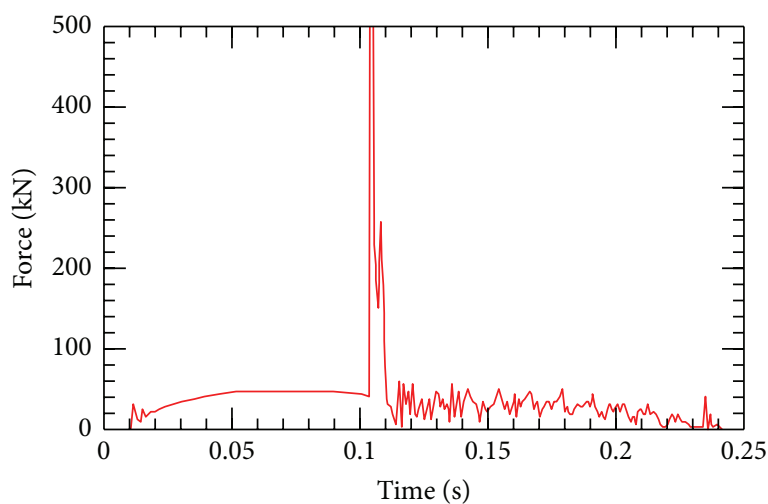

(h) $100 * 10$

Figure 11: Continued. 


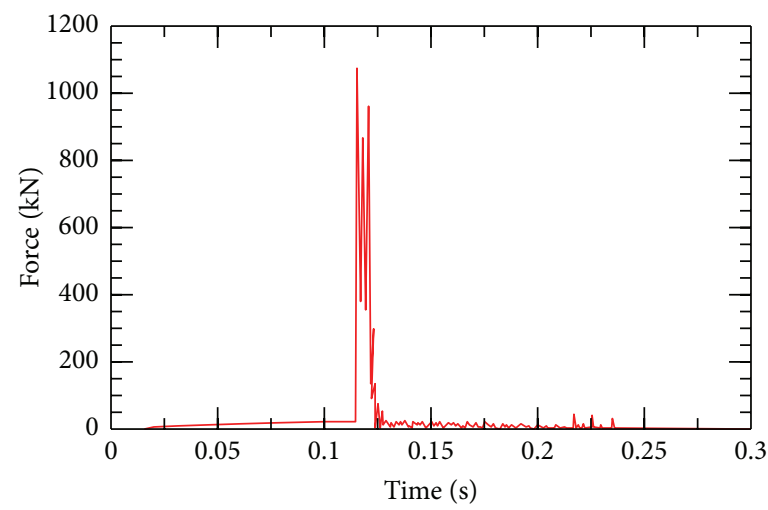

(i) $500 * 2$

Figure 11: Impact-time curve of slab.

TABLE 8: The process contrast of different mass of rockfall in the same energy level.

\begin{tabular}{lcccc}
\hline Rockfall energy/kJ & 1 & 1 & 3 & 3 \\
\hline Rockfall mass $/ \mathrm{kg}$ & 50 & 100 & 100 & 150 \\
Tire deformation $/ \mathrm{m}$ & 0.27 & 0.32 & 0.45 & 0.50 \\
Average impact force/kN & 4 & 4.28 & 6.9 & 7.69 \\
\hline
\end{tabular}

cushion and energy absorption measures are usually adopted. This paper proposes a used tire cushion layer for rock shed and carries out test and numerical simulation studies; results show that (1) used tire cushion layer can effectively cushion rockfall impact and reduce peak acceleration and maximum impact of rock shed slab; (2) cushion layer filled with sand and gravel can increase rigidity and energy absorption capacity but increases dead load of rock shed simultaneously; (3) with the same energy, rockfall with large mass is more unfavorable for cushion layer; (4) simplified calculation model can greatly improve the computational efficiency and the parameters for calculation are easy to obtain through test.

In practical engineering application, cushion layer can be set up with multilayer and filled with polyurethane foam, polystyrene, low-density industrial waste, or other lightweight materials with a cell structure in order to improve the rigidity and energy absorption capacity of cushion layer.

\section{Conflict of Interests}

The authors declare that there is no conflict of interests regarding the publication of this paper.

\section{Acknowledgments}

This work was supported by grant from National Natural Science Foundation of China (nos. 51378495 and 51408602), Chongqing Natural Science Foundation (cstc2012jjA30005, cstc2012jjB30004), and Bureau of Land Resources and Housing Management of Chongqing.

\section{References}

[1] Y. Huang, Q.-D. Sun, and Q. Xu, "New development of rockfall kinematics study," Journal of Vibration and Shock, vol. 29, no. 10, pp. 31-35, 2010.

[2] M. Wang, S.-Q. Shi, and J.-G. Kang, "Numerical and theoretical analysis of dissipation energy capacity of ring net impacted by rockfall," Journal of Vibration and Shock, vol. 30, no. 3, pp. 10-21, 2011.

[3] J. Su, C. Zhou, S.-S. Chen et al., "Numerical simulation of flexible gabion arch dam to prevent and control debris flow blocks," Chinese Journal of Geotechnical Engineering, vol. 37, no. 2, pp. 269-275, 2015.

[4] F. Descoeudres, "Aspects géomécaniques des instabilités de falaises rocheuses et des chutes de blocs," Publication de la Société Suisse de Mécanique des Sols et des Roches, no. 135, pp. 3-11, 1997.

[5] D.-P. Wang, S.-M. He, Y. Wu, and X.-P. Li, "Cusioning effect of rock sheds with EPS cushion on rock-falls action," Journal of Vibration and Shock, vol. 33, no. 4, pp. 199-214, 2014.

[6] F. Delhomme, M. Mommessin, J. P. Mougin, and P. Perrotin, "Behavior of a structurally dissipating rock-shed: experimental analysis and study of punching effects," International Journal of Solids and Structures, vol. 42, no. 14, pp. 4204-4219, 2005.

[7] M. Mommessin, A. Agbossou, F. Delhomme et al., "Horizontal and slanting reinforced concrete slabs for structurally dissipating rock-shed: experimental analysis," in Proceedings of the 5th International Conference on Fracture Mechanics of Concrete and Concrete Structures, V. C. Li, C. K. Y. Leung, and K. J. Willam, Eds., vol. Volume 2, pp. 965-972, American Concrete Institute, Vail, Colo, USA, April 2004.

[8] S.-M. He and Y. Wu, "Research on cushioning mechanism of new-typed energy dissipative rock shed," Chinese Journal of Rock Mechanics and Engineering, vol. 29, no. 5, pp. 926-932, 2010.

[9] Z. Boukria, P. Perrotin, A. Bennani, and A. Limam, "Experimental impact characterization on a Structurally Dissipating Rock-shed (SDR) structure," International Journal of Protective Structures, vol. 3, no. 1, pp. 21-36, 2012.

[10] N. Ishikawa, "Recent progress on rock-shed studies in Japan," in Joint Japan-Swiss Scientific Seminar on Impact Load by Rock Falls and Design of Protection Structures, P. Masuya and V. Labiouse, Eds., pp. 1-6, Ishikawa, Kanazawa, Japan, 1999. 
[11] H. Yoshida, T. Nomura, D. C. Wyllie et al., "Rock fall shedsapplication of Japanese designs in North America," in Proceedings of the 1st North American Landslide Conference, V. R. Schaefer, R. L. Schuster, and A. K. Turner, Eds., Landslides/slope Instability AEG Special Publication: Conference Presentations, pp. 179-196, The Association of Environmental \& Engineering Geologists, Vail, Colo, USA, June 2007.

[12] T. S. Ho, H. Masuya, and N. Takashita, "Experimental study concerning impact characteristics by collision of weight on sand cushion over steel beam," International Journal of GEOMATE, vol. 4, no. 1, pp. 471-476, 2013.

[13] K. Schellenberg, A. Volkwein, M. Denk, and T. Vogel, "Falling weight tests on rock fall galleries with cushion layers," in Proceedings of Interdisciplinary Workshop on Rockfall Protection, Morschach, Switzerland, June 23-25, 2008, A. Volkwein, V. Labiouse, and K. Schellenberg, Eds., pp. 99-101, 2008.

[14] W. Gerber, A. Volkwein, and M. Denk, "Impact of rockfalls on reinforced foam glass cushion systems," in Proceedings of the Interdisciplinary Workshop on Rockfall Protection, A. Volkwein, V. Labiouse, and K. Schellenberg, Eds., pp. 31-33, Morschach, Switzerland, June 2008.

[15] J. Lorentz, P. Perrotin, and F. Donzé, "A new sandwich design structure for protection against rockfalls," in Proceedings of the Interdisciplinary Workshop on Rockfall Protection, A. Volkwein, V. Labiouse, and K. Schellenberg, Eds., pp. 58-60, Morschach, Switzerland, June 2008.

[16] P. Zhang, Three Dimensional Finite Element Analysis and Study of Side-Drilling Characteristic for Radial Tire, Hefei University of Technology, Hefei, China, 2004.

[17] X.-M. Wang and M.-S. Yang, "Analysis for effect of belt on radial tire uniformity by FEA," Rubber Industry, vol. 51, no. 1, pp. 3539, 2004. 


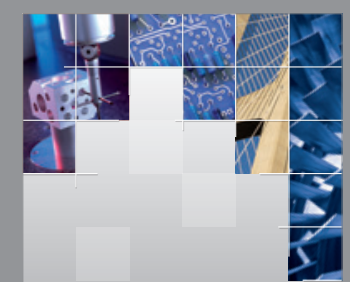

\section{Enfincering}
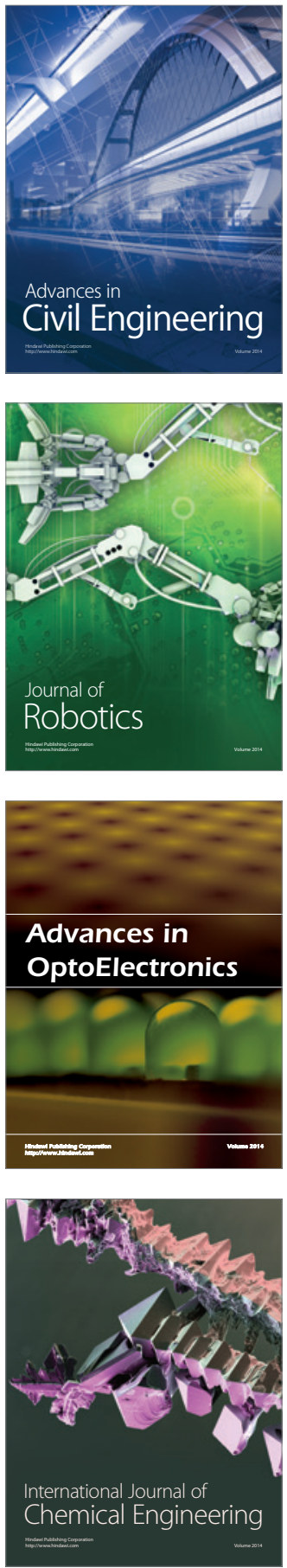

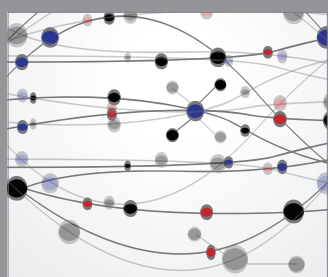

The Scientific World Journal

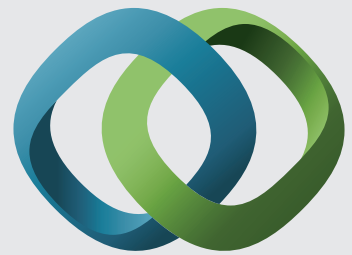

\section{Hindawi}

Submit your manuscripts at

http://www.hindawi.com
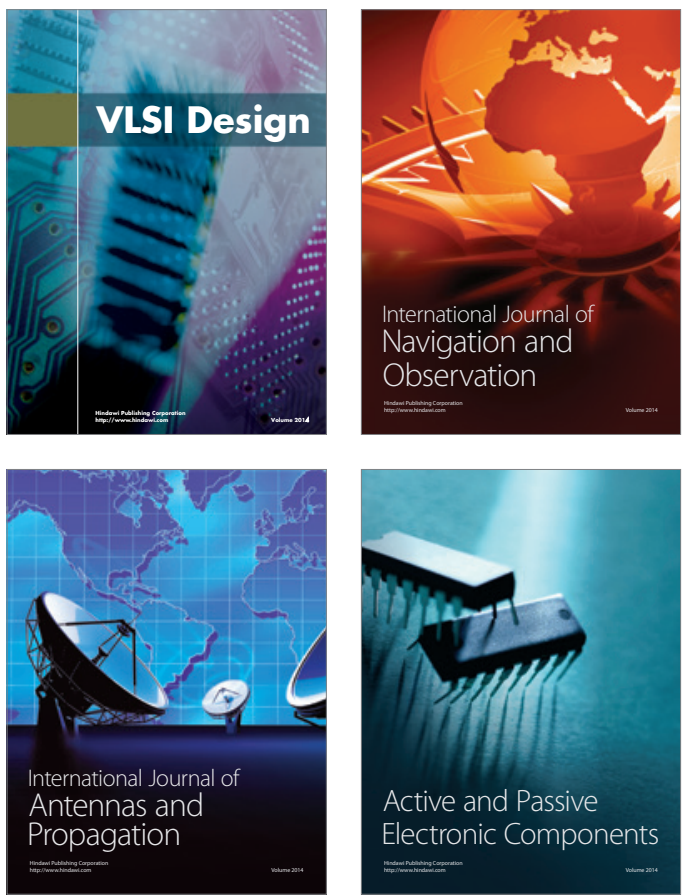
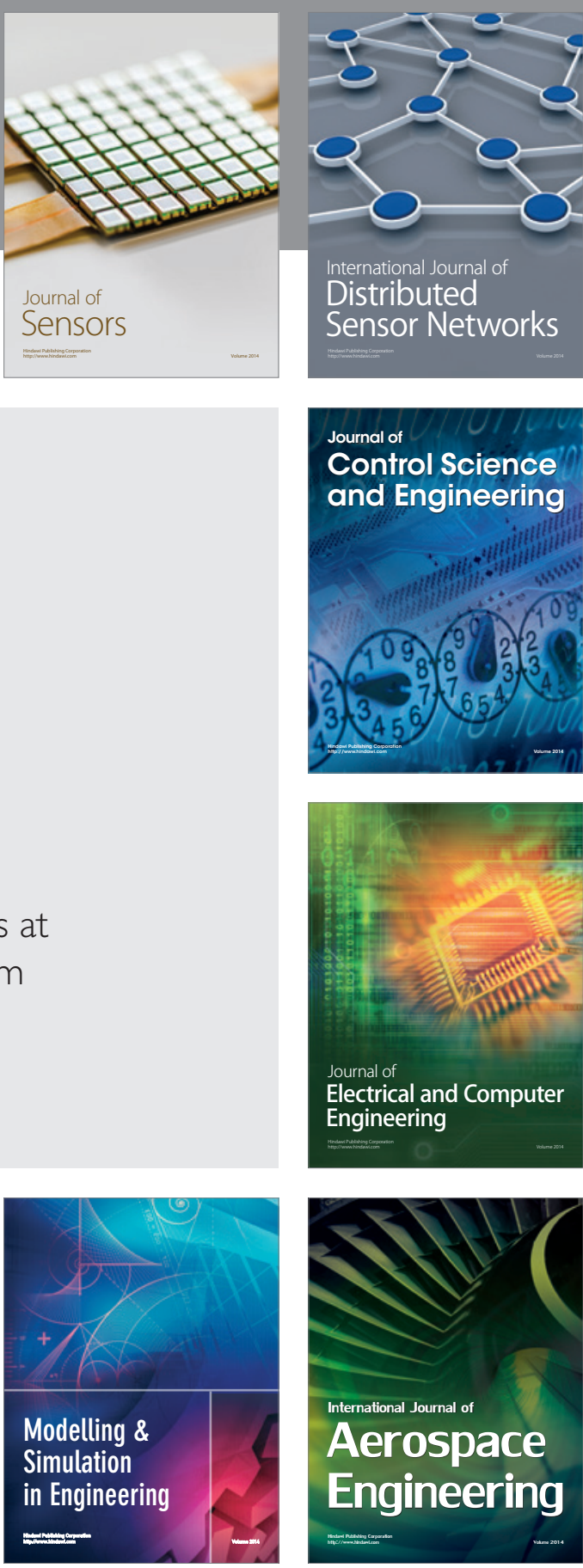

International Journal of

Distributed

Sensor Networks

Journal of

Control Science

and Engineering
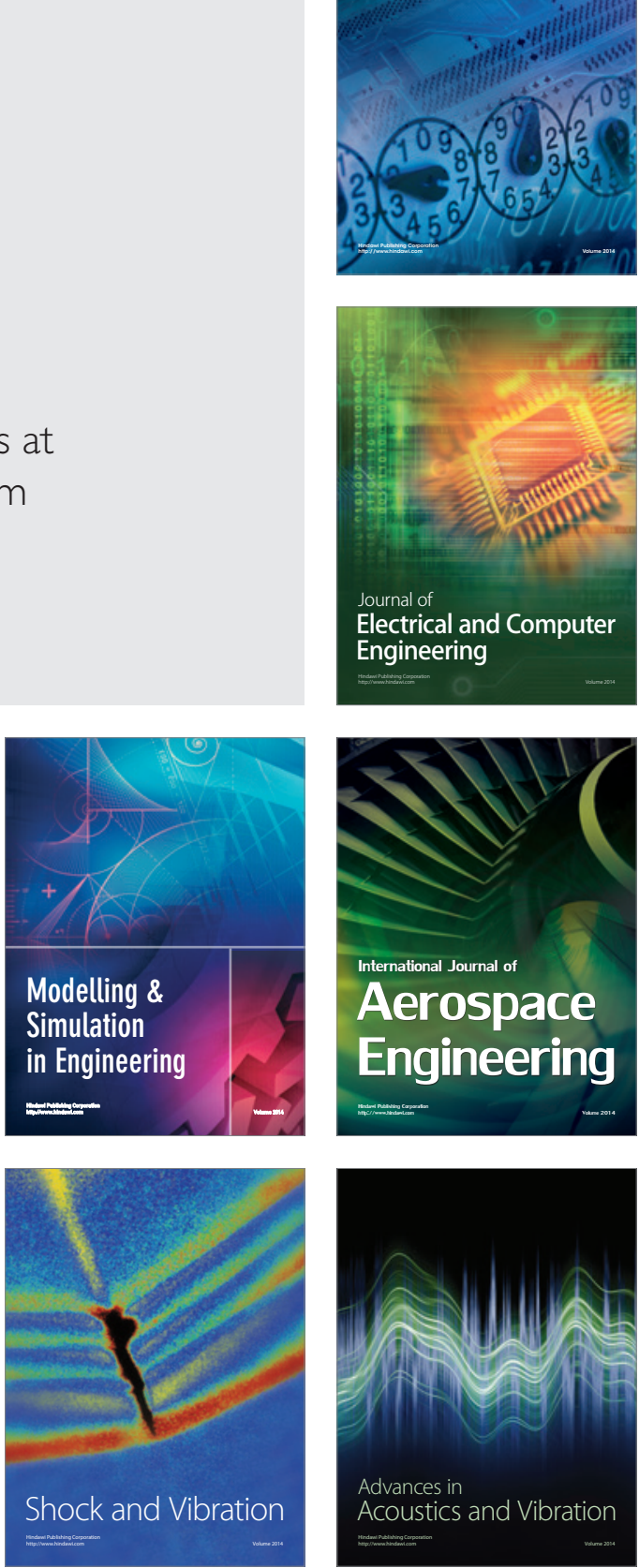